\title{
ROSMARINUS OFFICINALIS PULPOTOMY FOR VITAL PRIMARY MOLARS: A CLINICAL AND RADIOGRAPHIC STUDY
}

\author{
Ghada A. Elbaz* and Gihan G. El Desouky **
}

\begin{abstract}
Introduction: Pulpotomy is the most commonly attempted vital pulp therapy procedure to treat symptomless pulp exposures in primary teeth; however, the search for the ideal bactericidal and biocompatible medicament still continues despite the numerous clinical trials with different materials. Therefore, the aim of the present study was to clinically and radiographically evaluate the success rate of $6.25 \%$ aqueous extract of Rosmarinus officinalis in comparison to formecresol as a pulpotomy dressing medicament in vital primary molars.
\end{abstract}

Methods: Twenty-five children aged 4-7 year with bilateral vital mandibular primary first molars indicated for pulpotomy were included in the present study. They were divided into two groups (A) and (B), 25 molars each; where each side of the patient received a different pulpotomy medicament; $R$-officinalis and formecresol. Both groups were assessed clinically and radiographically for six months.

Results: After 6 months, the cumulative survival rates were $92.0 \%$ and $81.0 \%$ respectively for $R$-officinalis and formocresol with no statistically significant difference between the survival rates of the two medicaments. Clinical success for $R$-officinalis showed $96.0 \%$ while formocresol showed $88.0 \%$ clinical success. In addition, radiographic evaluation revealed higher mean interradicular bone density in the $R$-officinalis pulpotomy group when compared to the formocresol pulpotomy group.

Conclusions: Based on the high cumulative clinical and radiographic survival results revealed in the present study, Rosmarinus officinalis can be considered a successful alternative pulpotomy medicament for formocresol with promising results in the treatment of vital primary molars.

KEY WORDS: Vital pulpotomy- Herbal medicine- radiograph- clinical study- primary molar.

* Assistant Professor of Pediatric and Preventive Dentistry and Dental Public Health, Faculty of Dentistry, Suez Canal University.

** Assistant Professor of Oral Radiology, Faculty of Dentistry, Suez Canal University. 


\section{INTRODUCTION}

Pulpotomy is considered the accepted standard for pulp treatment of symptom-free primary teeth in children before 6 years of age (Huth et al. 2005 and Ruby et al. 2012). It is the procedure of choice when only the coronal pulp is inflamed due to bacterial penetration following carious, traumatic or iatrogenic causes, and the radicular pulp is free from inflammation. Formocresol has been a popular pulpotomy medicament in the primary dentition (Fuks 2008). The success rate of formocresol pulpotomy is 70-98\% (Holan et al, 2005; Bahrololoomi et al. 2008). However, several studies have reported its potential for local and systemic side effects; such as local pulpal inflammation or necrosis, general cytotoxicity, mutagenic or carcinogenic effect, systemic disturbances, and immunologic responses (Farsi et al. 2005). Since common dental dressing materials have many sideeffects; in association to their high costs, tendency towards using alternative and traditional cheaper treatments is increasing (Farrokh 2011and Jose et al. 2013). A great amount of research has been done on herbs to investigate their effects in the dental field (Haghgoo et al. 2011and Poureslami et al. 2013). One of these herbs is Rosmarinus officinalis (R-officinalis), commonly referred to as Rosemary, which belongs to the mint family. It is a common dense, evergreen, aromatic shrub grown in many parts of the world (Moss et al.2003). R-officinalis has demonstrated pharmacological action as a digestive, antispasmodic (Porte and Godoy 2001), antiinflammatory (Takaki et al. 2008), antiproliferative, antioxidant(Cheng etal.2011). Many studies confirm the antimicrobial potential effect of the $R$-officinalis as treatment for multiple oral conditions. (Bugno et al. 2006; Alvarenga et al. 2007; Bernardes et al. 2010; Maekawa et al. 2010 and Sasaki et al. 2013). However, despite these documented antimicrobial properties, up to our knowledge, its specific use as a pulpotomy medicament has not yet been investigated. Therefore, the aim of the present study was to evaluate the success rate of $6.25 \%$ aqueous extract of $R$-officinalis as pulpotomy dressing medicament in vital primary molars both clinically and radiographically in comparison to formecresol pulpotomy.

\section{MATERIALS AND METHODS}

Twenty five children of both sexes, ranging in age from four to seven years, were selected from the Clinic of the Pedodontic Department, Faculty of Dentistry, Suez Canal University, Ismailia, Egypt. The children included in the present study were chosen to be cooperative according to the Frankl Behavioral Rating Scale ratings 3-positive and 4-definitely positive. For all children, past and present medical histories were taken to exclude children suffering from any medical problems that may interfere with dental treatment.

Based on clinical and radiographic screening, the inclusion criteria for the selected children were as follows:

- All selected children had bilateral vital mandibular primary first molars with deep carious lesion.

- Absence of clinical signs or symptoms suggesting a non-vital tooth, such as spontaneous pain, presence of abscess, soft tissue swelling or suppurating sinus.

- Absence of radiographic changes as; furcation, or periapical pathology, internal or external root resorption or calcification in the canals.

- The tooth structure of selected molars should be restorable after completion of the treatment with stainless steel crowns.

Full detailed treatment plans were explained to the children's parents or guardians and written consents for treatment were obtained prior to clinical procedures. The selected primary molars were randomly assigned and divided into two groups, 25 each; depending on the type of 
pulpotomy medicaments used, where left side of the odd patients received $R$-officinalis as pulpotomy medicament and formecresol was used for the right side, while for the even patients numbers, $R$ officinalis was used as pulpotomy medicament for the right side and formecresol for the left side (split mouth technique).

\section{Clinical Procedure}

After administering local anesthesia, the tooth was isolated with a rubber dam. All caries were removed and coronal access was gained using a sterile No. 330 bur mounted on a water-cooled high speed turbine to expose the pulp chamber. A spoon excavator was used for coronal pulp amputation. Pulp chamber was then irrigated with saline to remove all debris. Haemostasis was obtained with a moistened cotton pellet gently pressed against the amputated pulp stumps in both groups. Hemorrhage should stop within 5 min from the application of the cotton pellet.

In the R-officinalis (experimental group) Group A: A sterile cotton pellet dipped and squeezed in $6.25 \%$ aqueous extract of $R$-officinalis was placed over the radicular pulp for 5 minutes. Then, the pulp chamber was sealed with a thick paste formed of zinc-oxide powder and aqueous extract of $R$-officinalis.

In the formocresol (control group) Group B: A sterile cotton pellet dipped and squeezed in diluted formocresol (Buckely's formocresol, manufactured in USA for Sultan Healthcare) was placed over the radicular pulp for 5 minutes then the pulp chamber was covered with a thick mix of zinc oxide and eugenol.

A thick mix of zinc phosphate cement was applied in both groups to cover the pulpotomy medicament. The coronal parts were restored by preformed stainless steel crowns (3M Co, US). All pulpotomies were performed by the same operator (first author) as a one-stage treatment.

\section{Radiographic Evaluation}

After completion of the treatment procedures, immediate postoperative peri-apical radiographs were taken using size 1 Kodak films employing the Rinn XCP alignment system (Rinn Corporation, Elign, $I L)$ and the long cone paralleling technique for standardization. All films were exposed using the dental x-ray machine (Fona XDC, Via Galilei, Assago, Italy) at $70 \mathrm{kvp}$ and 8 ma for 0.3 seconds. The immediate postoperative radiograph served as a base line record for the successive films. Peri-apical radiographs were processed using an automatic processor (Extra-X Velopex, Medivance Instruments Limited, London, England) for standardization of image density and contrast then digitized using a transparency scanner (HP Scanjet G3110; HewlettPackard Development CO, Palo Alto, CA). The radiographic technique and exposure parameters were considered fixed for all patients and were repeated for the follow-up recalls. Images were then transferred to a PC computer for further linear and density analysis which were carried out using Digora image analysis software (Digora for windows 2.5, Sordex Finndent, Finland). The same radiographic records and measurements were obtained twice at different times by the same examiner (second author), who was blind to the type of pulpotomy medicament used. The average readings were recorded and used for comparisons between successive radiographs and for statistical analysis. In the present study, all children completed the follow-up evaluation period. They were recalled after one week for clinical evaluation, then after one, three and six months respectively for clinical and radiographic evaluation.

\section{Clinical and Radiographic follow-up}

The below listed criteria were used for clinical and radiographic assessment of both pulpotomy medicaments. The clinical evaluation criteria consisted of the presence or absence of:

- Pain,

- Tenderness to percussion, 
- Swelling or abscess,

- Abnormal tooth mobility.

The radiographic evaluation criteria used were:

- Width of the periodontal membrane space in the furcation area (exactly at the middle of the furcation area and assessed in millimeters).

- Presence or absence of internal root resorption / external root resorption.

- Radio-density of bone at the furcation area to assess the effect of the puplotomy medicament on alveolar bone.

(The average area radio-density was similarly measured at the middle of the furcation area; it was numerically calibrated by quantifying the image on a 256 gray scale value where 0 represents totally radiolucent and 255 represent totally radio-opaque). The same area was measured in subsequent radiographs and the average radio-densities were recorded for the follow-up radiographs. (Fig 1)

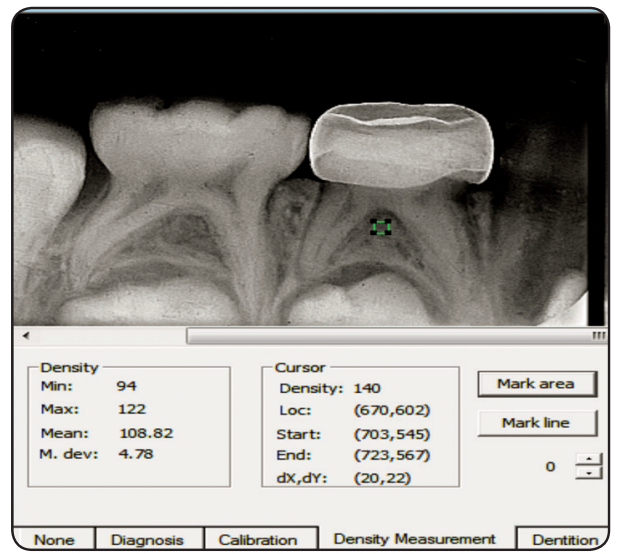

Fig. (1): A radiograph shows the inter-radicular alveolar bone density measurements using the Digora 2.5 software.

\section{Preparation of Rosmarinus officinalis extract}

The extraction process was done at Department of Pharmacognosy, Faculty of Pharmacy, Suez Canal University. The leaves of $R$-officinalis were collected from the garden of Faculty of Agriculture, Suez Canal University. The leaves of $150 \mathrm{~g}$ weight $R$-officinalis were grinded using mortar and pestle to increase surface area for better extraction. Then, they were boiled in $1500 \mathrm{ml}$ distilled water in a water bath for four hours and soaked for four days. The whole process of decoction, soaking and filtration was repeated five times and the supernatant was filtered prior to drying at room temperature (Changizi Ashtiyani et al. 2013). 6.25\% aqueous extract solution was prepared by dissolving $6.25 \mathrm{~g}$ of extract in $100 \mathrm{ml}$ distilled water using filtrasonicator for 30 minutes.

\section{Statistical Analysis}

Qualitative data were presented as frequencies (n) and percentages (\%). McNemar's test was used to compare between clinical success rate of the two techniques. Data were presented as mean and standard deviation (SD) values. Wilcoxon signedrank test was used to compare between the two techniques. Friedman's test was used to study the changes by time within each technique. Cox regression analysis was used to study the survival rates of the two techniques using life tables and survival curve and Wilcoxon statistic test was used to compare between survival rates of the two techniques.

\section{RESULTS}

The present study was conducted on 25 children; 15 boys $(60.0 \%)$ and 10 girls (40.0\%). The mean and standard deviation values of their age were $5.6 \pm 1.1$ years with a minimum of 4 years and a maximum of 7 years.

\section{Clinical success rate}

Upon clinically evaluating the overall criteria for success both medicaments of pulpotomy resulted in $100.0 \%$ clinical success after 1 week as well as after 1 month. After 3 months, R-officinalis group showed $100.0 \%$ clinical success while formocresol group showed $96.0 \%$ clinical success, however, this difference was not statistically significant ( $P$-value $=1.000)$. The cause of failure in formocresol group was abscess formation, as well as pain on percussion 
and tooth mobility in one case. After 6 months, $R$-officinalis showed $96.0 \%$ clinical success while formocresol showed $88.0 \%$ clinical success. The causes of failure in R-officinalis pulpotomy was pain on percussion while in formocresol group were fistula formation, pain on percussion, mobility and one tooth was extracted. However, the difference between the two medicaments was not statistically significant $(P$-value $=1.000)($ Table 1$)$.

Table (1): Frequencies (n), percentages (\%) and results of McNemar's test for comparison between clinical success rates of the two pulpotomy techniques.

\begin{tabular}{|c|c|c|c|c|c|}
\hline \multirow{2}{*}{ Time } & \multicolumn{2}{|c|}{$R$-officinalis } & \multicolumn{2}{|c|}{ Formocresol } & \multirow{2}{*}{$P$-value } \\
\cline { 2 - 5 } & $\mathrm{n}$ & $\%$ & $\mathrm{n}$ & $\%$ & \\
\hline $3 \mathrm{~ms}$ & 25 & 100.0 & 24 & 96.0 & 1.000 \\
\hline $6 \mathrm{~ms}$ & 24 & 96.0 & 22 & 88.0 & 1.000 \\
\hline
\end{tabular}

*: Significant at $P \leq 0.05$

\section{Survival analysis}

After 6 months, the cumulative survival was $92.0 \%$ and $81.0 \%$ for $R$-officinalis and formocresol, respectively. However, there was no statistically significant difference between survival rates of the two medicaments $(P$-value $=0.293)$. According to survival analysis, the median survival time was 6 months with each medicament (Fig 2).

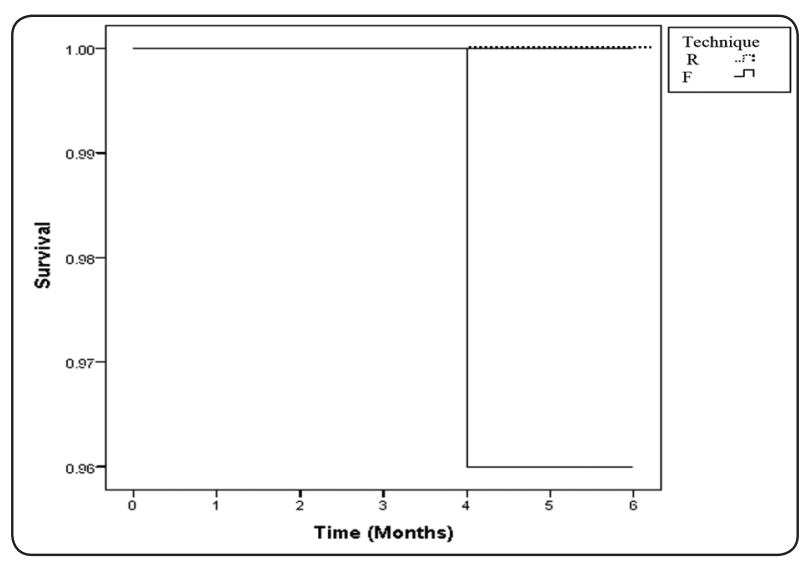

Fig. (2): Overall survival curves of the two techniques (R: R-officinalis, F: Formocresol)

\section{Radiographic results}

Neither of the two groups showed radiographic signs of internal or external root resorption after 1 , 3 as well as 6 months.

\section{Width of periodontal membrane space}

At base line, after 1, 3 as well as 6 months; $R$-officinalis pulpotomy showed lower mean width of periodontal membrane space than formocresol pulpotomy. As regards the changes by time within $R$-officinalis pulpotomy, there was a statistically significant increase in mean width seen only after 6 months compared to base line measurement. While for formocresol pulpotomy, the width at 3 months and 6 months showed statistically significantly higher mean value than base line (Table 2).

TABLE (2): Mean, standard deviation values and results of Friedman's test and Wilcoxon signed-rank test for comparisons of width of periodontal membrane space between the two pulpotomy techniques

\begin{tabular}{|c|c|c|c|c|c|}
\hline \multirow[b]{2}{*}{ Time } & \multicolumn{2}{|c|}{$R$-officinalis } & \multicolumn{2}{|c|}{ Formocresol } & \multirow{2}{*}{$\begin{array}{c}P \text {-value } \\
\text { (Between } \\
\text { techniques) }\end{array}$} \\
\hline & Mean & SD & Mean & SD & \\
\hline Base line & $0.08^{\text {в }}$ & 0.02 & $0.10^{\mathrm{B}}$ & 0.03 & $0.002 *$ \\
\hline 1 month & $0.09 \mathrm{AB}$ & 0.03 & $0.11 \mathrm{AB}$ & 0.04 & $0.003^{*}$ \\
\hline 3 months & 0.09 Ав & 0.04 & $0.12^{\mathrm{A}}$ & 0.05 & $<0.001 *$ \\
\hline 6 months & $0.10^{\mathrm{A}}$ & 0.05 & $0.12^{\mathrm{A}}$ & 0.06 & $0.002 *$ \\
\hline $\begin{array}{l}P \text {-value } \\
\text { (Changes } \\
\text { by time) }\end{array}$ & \multicolumn{2}{|c|}{$0.006^{*}$} & \multicolumn{2}{|c|}{$<0.001 *$} & \\
\hline
\end{tabular}

*: Significant at $P \leq 0.05$, Different superscripts in the same column are statistically significantly different

\section{Inter-radicular bone radio-density}

At base line, there was no statistically significant difference between the two medicaments. However, after 1,3 as well as 6 months; $R$-officinalis pulpotomy showed higher mean inter-radicular bone density than formocresol pulpotomy. 
As regards the changes by time within $R$-officinalis pulpotomy, there was no statistically significant change in inter-radicular bone density from base line to 1 month; however, from 1 month to 3 months as well as from 3 months to 6 months, there was a statistically significant increase in mean inter-radicular bone density (Fig 3). While for formocresol pulpotomy, there was a statistically significant decrease in inter-radicular bone density from base line to 1 month as well as from 1 month to 3 months. From 3 months to 6 months, there was no statistically significant change in mean interradicular bone density. The mean inter-radicular bone density after 6 months showed statistically significantly lower mean value than base line bone density. (Fig 4)(Table 3)
TABLE (3): Mean, standard deviation values and results of Friedman's test and Wilcoxon signed-rank test for comparisons of inter-radicular density between the two pulpotomy techniques

\begin{tabular}{|c|c|c|c|c|c|}
\hline \multirow{2}{*}{ Time } & \multicolumn{2}{|c|}{$R$-officinalis } & \multicolumn{2}{c|}{ Formocresol } & \multirow{2}{*}{$\begin{array}{c}P \text {-value } \\
\text { (Between } \\
\text { techniques })\end{array}$} \\
\hline Base line & $101.83^{\mathrm{C}}$ & 13.80 & $102.04^{\mathrm{A}}$ & 16.07 & 0.989 \\
\hline 1 month & $103.77^{\mathrm{C}}$ & 14.52 & $95.08^{\mathrm{B}}$ & 16.97 & $<0.001^{*}$ \\
\hline 3 months & $108.10^{\mathrm{B}}$ & 16.26 & $87.20^{\mathrm{C}}$ & 19.88 & $<0.001^{*}$ \\
\hline 6 months & $112.79^{\mathrm{A}}$ & 21.84 & $83.31^{\mathrm{C}}$ & 25.51 & $<0.001^{*}$ \\
\hline $\begin{array}{c}P \text {-value } \\
\begin{array}{c}\text { (Changes } \\
\text { by time) }\end{array}\end{array}$ & \multicolumn{2}{|c|}{$<0.001^{*}$} & $<0.001^{*}$ & \\
\hline
\end{tabular}

*: Significant at $P \leq 0.05$, Different superscripts in the same column are statistically significantly different

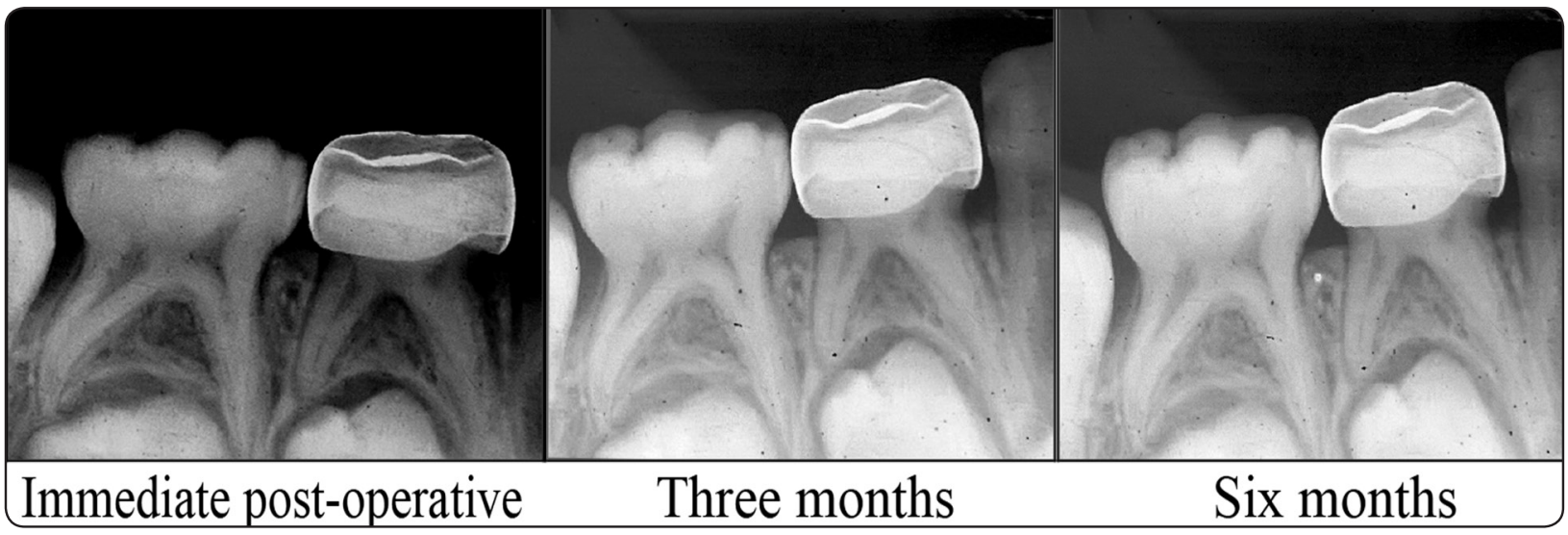

Fig. (3): Successive peri-apical radiographs for a case of R-officinalis pulpotomy radiographic success. Radiographs show gradual increase in inter-radicular bone density.

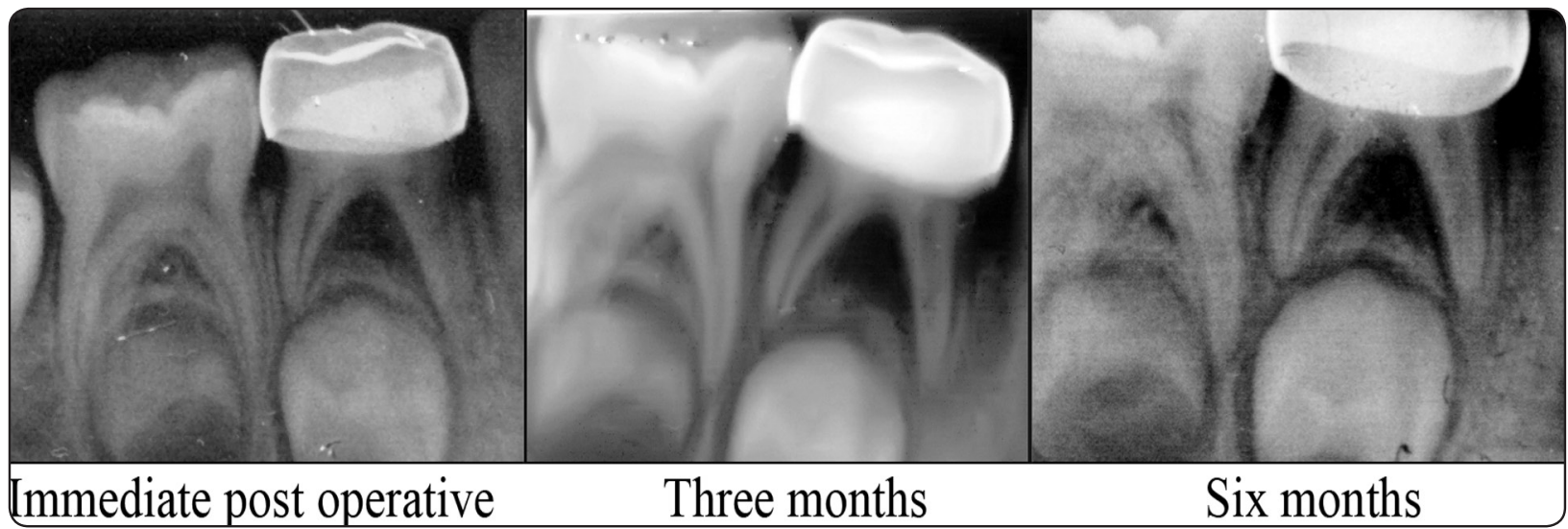

Fig. (4): Successive periapical radiographs for a case of formocresol pulpotomy radiographic failure. Radiographs show gradual decrease in inter-radicular bone density. 


\section{DISCUSSION}

Rosmarinus officinalis has obvious antibacterial and pharmacological activities effective for treatment of multiple oral infectious diseases (Bernardes et al. 2010; Paula et al. 2014). However, its use in pediatric dentistry has not been yet the subject of dental research. Therefore, the aim of the present study was to evaluate the success and efficacy of $6.25 \%$ aqueous extract of $R$-officinalis as pulpotomy dressing in vital primary molars both clinically and radiographically. In the current study, $6.25 \%$ aqueous extract of $R$-officinalis was chosen to be used in accordance to results of a previous study conducted by Alnamer et al.(2013). The authors found that the aqueous extract of $R$-officinalis at $6.25 \mathrm{mg} / \mathrm{ml}$ concentration possessed the minimal inhibitory concentration against the tested bacterial strains, both gram-positive and gram-negative. Therefore, the choice of this specific concentration was carried out. In the present study, children from 4 to 7 years of age with carious mandibular primary first molars indicated for pulpotomy treatment were included. This age group was selected to avoid the lack of cooperation of younger children and physiologic root resorption in elder ones. Mandibular molars were chosen to be assessed in our study since they are easier to be clinically visualized and radio-graphed; in addition they show more accurate radiographic interpretation than maxillary ones due to lack of superimposition of the palatal root. In the present study, after 6 months the results revealed that the clinical success rate of $R$ officinalis was $96 \%$, while the clinical success rate of formocresol was $88 \%$. This result confirmed the clinical success rate of formocresol in treatment of vital primary molars and was in agreement with the results of numerous previous studies conducted on formocresol (Markovic et al. 2005; Mohammad et al. 2014). In our study, the causes of failure in the formocresol group were fistula formation, pain on percussion and mobility. This can be explained by the incomplete pulp fixation resulted from formecresol and by its suggested toxicity, which in turn lead to the high susceptibility of periapical changes and abscess formation (Markovic et al. 2005). The promising clinical outcome of vital pulpotomy performed with $R$ - officinalis (96\%) may be explained on the bases that $R$-officinalis has documented anti-inflammatory, antioxidant and antimicrobial properties (Abdul sattar et al. 2012). This plant extracts is made up of essential oil, flavonoids, phenols and terpenoids, lectins, polypeptides, proanthocynidins, tannins, and quercetin, all of which constitute the basis of the antimicrobial activity of its extract (Cowan 1999). Radio-graphically, the width of the periodontal membrane space in the furcation area as well as the inter-radicular bone density was independently analyzed for more accurate assessment of signs of alveolar bone reaction to the type of pulpotomy medicament used. Regarding the changes by time within formocresol pulpotomy, the width of periodontal membrane space at 3 months and 6 months showed statistically significantly higher mean value than base line, in addition, the radiographic findings showed decrease in interradicular bone density in all examined periods in comparison to the base line. This may be attributed to the formocresol medicament's ability to fix the remaining pulp tissue, rather than to stimulate the healing response of the remaining pulp tissue (Markovic et al. 2005).In addition, the small molecule of formaldehyde can penetrate into the apical region through the pulpal canal(s) or into the furcation area via accessory canals or the pulpal floor, as it is thin, porous and permeable in nature, in deciduous molars leading to alveolar bone inflammation (Curzon et al. 2002).This inflammation in the alveolar bone at the furcation region is primarily represented radio-graphically as widening in the periodontal ligament space, then, alveolar bone inflammation and subsequent decrease in bone radio-density occurs (Srinivasan and Jayanthi 2011). Nevertheless, the use of digital 
image analysis using the Digora system allowed more accurate assessment of millimeter linear changes in the periodontal ligament space width and quantitative radio-density measurements for the alveolar bone changes. The gray scale value of pixels is more accurately evaluated with higher degrees of sensitivity undetectable by the human eye (Salzedas et al. 2006). This could explain the relatively higher radiographic results for formocresol failure that could have otherwise been unobservable. In the present study, radiographic investigation of the $R$ - officinalis group showed an improvement and significant increase in the inter-radicular bone radiodensity at the end of the follow-up period indicating more bone formation and increased osteoblastic activity. Al-Sereiti et al. (1999) concluded that $R$ officinalis and its constituents (caffeic acid and its derivative rosmarinic acid) have a therapeutic potential in treatment or prevention of inflammatory process. These compounds increase the production of prostaglandin E2, reduce the production of leukotriene B4 in human poly-morphonuclear leucocytes, and inhibit the complement system. This could explain the ability of $R$-officinalis in the treatment of inflamed inter-radicular bone and promoting its healing. However, a longer follow-up period, till the time of tooth shedding, is recommended for more accurate evaluation of R-officinalis use in vital pulpotomy of primary molars.

\section{CONCLUSIONS}

Based on the high cumulative clinical and radiographic survival rates, $R$ - officinalis can be considered a successful alternative pulpotomy medicament for formocresol with promising results in the treatment of vital primary molars.

\section{REFRENCESES}

1- Abdul sattar B, Hassan A, Hassan A. In Vitro Antimicrobial Activity of Thymus Vulgaris, Origanum Vulgare and Rosmarinus Officinalis Against Dental Caries Pathogens.
Ibn Al-Haitham Journal for Pure and Applied Science 2012; 25(2):336-342.

2- Alnamer R, Alaoui K, Doudach L, Al-Sobarry M, Bouidida El H, Fatiha Chibani, Benjouad A and Cherrah Y. In vitro antibacterial activity of rosmarinus officinalis methanolic and aqueous extracts Int J Pharm 2013; 3(1): 1-6.

3- Al-Sereiti M, Abu-Amer K, Sen P. Pharmacology of rosemary (Rosmarinus officinalis Linn.) and its therapeutic potentials. Indian J. Exp. Biol 1999; 37(2):124-130.

4- Alvarenga A, Schwan R, Dias D, Schwan-Estrada K, Bravo-Martins C. Atividade antimicrobiana de extratos vegetais sobre bactérias patogênicas humanas. Rev. Bras. Pl. Med 2007; 9(4)86- 91.

5- Bahrololoomi Z, Moeintaghavi A, Emtiazi M, Hosseini G. Clinical and radiographic comparison of primary molars after formocresol and electrosurgical pulpotomy: randomized clinical trial. Indian J Dent Res 2008; 19(3):219-224

6- Bernardes W, Lucarini R, Tozatti M, Souza M, Silva M, Da Silva Filho A, Martins C, Crotti A, Pauletti P, Groppo M, and Cunha W. Antimicrobial activity of Rosmarinus offi cinalis against oral pathogens: The relevance of carnosic acid and carnosol. Chem. Biodivers 2010; 7: 1835 -1840 .

7- Bugno A, Buzzo A, Nakamura C, Pereira T, Matos D, Pinto T. Avaliação da contaminação microbiana em drogas vegetais. Rev. Bras. Ciên. Farm 2006; 41(1):491-497.

8- Changizi-Ashtiyani S, Zohrabi M, Hassanpoor A. Oral administration of the aqueous extract of Rosmarinus officinalis in rats before renal reperfusion injury. Iran J Kidney Dis 2013; 7(5): 367-75.

9- Cheng A, Lee M, Tsai M. .Rosmanol potently induces apoptosis through both the mitochondrial apoptotic pathway and death receptor pathway in human colon adenocarcinoma COLO 205 cells. Food Chem Toxicol 2011; 49:485-493.

10- Cowan M. Plant products as antimicrobial agents. Clin Microbiol Rev 1999;12:564-582.

11- Curzon M, Roberts J, Kennedy D..editors. Kennedy's Paediatric Operative Dentistry. 4th ed. Oxford:Wright. 2002;15(18):159-161.

12- Farrokh E. Comparison of three pulpotomy agents in primary molars: A randomized clinical trial. Iranian Endo J 2011; 6:11-14. 
13- Farsi N, Alamoudi N, Balto K, Mushayt A. Success of mineral trioxide aggregate in pulpotomized primary molars. J Clin Pediatr Dent 2005; 29(4):307-311.

14- Fuks AB. Vital Pulp Therapy with New Materials for PrimaryTeeth: New Directions and Treatment Perspectives. Pediatric Dentistry 2008; 30: 211-219.

15- Haghgoo R, Marasouli P ,Mehran M, Jalali -Nadoshan MR, Naseri M, Tavasoli S.. Histological evaluation of the pulp of primary teeth after pulpotomy with formocresol and SUAB2.J Islam Dent Asso of Iran. 2011; 23: 110-115.

16- Holan G, Eidelman E, Fuks AB. Long-term evaluation of pulpotomy in primary molars using mineral trioxide aggregate or formocresol. Pediatr Dent 2005; 27(2):129-136.

17- Huth KC, Paschos E, Hajek-Al-Khatar N, Hollweck R, Crispin A, Hickel R, Folwaczny M. Effectiveness of 4 pulpotomy techniques-randomized controlled trial. J Dent Res 2005; 84 (12):1144-1148.

18- Jose B, Ratnakumari N, Mohanty M, Varma HK, Komath M. Calcium phosphate cement as an alternative for formocresol in primary teeth pulpotomies.Indian J Dent Res 2013; 24:522-525.

19- Maekawa L, Brighenti F, Lamping R, Oliveira L, Marcacci S, Koga-Ito C. Atividade antimicrobiana de enxaguatórios bucaissemálcool à base de clorexidina sobre Candida albicans. Rev. Odontol. UNESP 2010; 39(1): 15-19.

20- Markovic D, Zivojinovic V, Vucetic M. Evaluation of three pulpotomy medicaments in primary teeth. Eur J Paediatr Dent 2005; 6(3): 133-138.

21- Mohammad S, Raheel S, Baroudi K. Clinical and Radiographic Evaluation of Allium sativum Oil as a New Medicament for Vital Pulp Treatment of Primary Teeth. J Int Oral Health2014; 6(6): 32-36.
22- Moss M, Cook J, Wesnes K, Duckett P. Aromas of rosemary and lavender essential oils differentially affect cognition and mood in healthy adults. Int J Neurosci. 2003; 113: $15-38$.

23- Paula I, Moraes F, De Souza O, Yamamoto C. Development of mouthwash with Rosmarinus officinalis extract. Braz J Pharm Sci 2014; 50(4): 851-858.

24- Porte A. and Godoy R. Alecrim (Rosmarinus officinalis L.): propriedades antimicrobiana e química do óleo essencial. B. do CEPPA 2001; 19(2) :193-210.

25- Poureslami HR, Khoramian S, Moulaie MM, Torabi M. 2013. Radiographic and histological evaluation of pulpotomized dogs primary teeth by Elaeagnus Angostifolia extract(a pilot study). Wulfenia J 2013; 20:323-330.

26- Ruby JD, Cox CF, Mitchell SC, Makhija S, Chompu-Inwai $\mathrm{P}$, Jackson J. A randomized study of sodium hypochlorite versus formocresol pulpotomy in primary molar teeth. Int J Paediatr Dent 2012; 13:1-8.

27- Salzedas LMP, Louzada MJQ, Oliveira Filho AB. Radiopacity of restorative materials using digital images. J Appl Oral Sci 2006; 14:147-152.

28- Sasaki K, El Omri A, Kondo S, Han J, Isoda H. Rosmarinus officinalis polyphenols produce anti-depressant like effect through monoaminergic and cholinergic functions modulation. Behav. Brain Res 2013;. 238(1)86- 94.

29- Srinivasan D and Jayanthi M. Comparative evaluation of formocresol and mineral trioxide aggregate as pulpotomy agents in deciduous teeth. Indian J Dent Res. 2011; 22(3):385-390.

30- Takaki I, Bersani A, Vendruscolo A, Sartoretto S, Diniz S, Bersani-Amado C. Anti-inflammatory and antinociceptive effects of Rosmarinus officinalis L. essential oil in experimental animal models. J. Med. Food 2008; 11(4):741-746. 